\title{
MORAL GRANDSTANDING AS A THREAT TO FREE EXPRESSION*
}

\author{
By Justin TOSI AND BRANDON WarmKe
}

\begin{abstract}
Moral grandstanding, or the use of moral talk for self-promotion, is a threat to free expression. When grandstanding is introduced in a public forum, several ideals of free expression are less likely to be realized. Popular views are less likely to be challenged, people are less free to entertain heterodox ideas, and the cost of changing one's mind goes up.
\end{abstract}

KEY WORDS: grandstanding, virtue signaling, free speech, status seeking, prestige, social media, shaming, moralizing

People contribute to public discourse for many reasons. Some are more morally laudable than others. This essay is about one less laudable form of contribution to public discourse-moral grandstanding - and its conflict with more laudable forms. In our view, moral grandstanding, or the use of moral talk for self-promotion, is a threat to free expression. When grandstanding is introduced in a public forum, popular views are less likely to be challenged, people are less free to entertain new and heterodox ideas, and the cost of changing one's mind goes up.

We'll begin by giving a brief account of what moral grandstanding is and why people do it. Next, we'll describe what forms we should expect grandstanding to take-in other words, how people often behave in public discourse when they are grandstanding. Having presented our account of grandstanding, we will then argue that it interferes with free expression in important ways.

\section{What Is Moral Grandstanding?}

The general phenomenon of grandstanding appears in countless areas of life. Many of these specific applications have their own terminology. People grandstand, showboat, hot-dog, vie for attention, or "play to the cheap seats" by contriving showy demonstrations of their wealth, intellect,

* We are grateful to David Schmidtz for the invitation to submit to Social Philosophy and Policy. An early version of this essay was presented at the AAUP Annual Conference on the State of Higher Education in Arlington, Virginia in the summer of 2018. We thank the participants at that conference for their comments. We also appreciate the comments of two anonymous referees, which helped improve the essay. article, distributed under the terms of the Creative Commons Attribution-NonCommercialNoDerivatives licence (http:/ / creativecommons.org/licenses/by-nc-nd/4.0/), which permits non-commercial re-use, distribution, and reproduction in any medium, provided the original work is unaltered and is properly cited. The written permission of Cambridge University Press must be obtained for commercial re-use or in order to create a derivative work. 
religious devotion, athletic prowess, class membership, and so on. There is no doubt much to say about each of these different types of grandstanding, but our focus is on the moral domain.

Put roughly, moral grandstanding is the use of moral talk for selfpromotion. More precisely, grandstanding has two essential elements. ${ }^{1}$ First, grandstanders want others to be impressed with their moral qualities-that is, the purity of their moral beliefs, their level of commitment to justice, their skill at discovering moral insights, and so on. We call this the "Recognition Desire." Second, grandstanders try to satisfy that desire by contributing some expression to public moral discourse. We call that public display the "Grandstanding Expression." Taken together, the basic idea is that a person grandstands when she says or writes something as part of some public moral discussion in an attempt to impress others with her putative moral qualities.

People grandstand to impress different kinds of audiences. Some might aim their grandstanding at a particular group-say, those who share a political ideology, or just those who agree with them about a single moral issue. Someone might say, for instance, "as a patriotic American, I support our troops on the ground, and I will not tolerate any criticism of their mission by those who would give aid and comfort to our enemies." Or, "I have long stood on the side of the least advantaged, and against the corporate fat-cats who exploit them by paying starvation wages." Each of these examples emphasizes the moral credentials of the speaker, which is common of grandstanding expressions. For those who grandstand to appeal to a subset of the public, the target is their in-group, and the goal is to raise their status among their fellow group members, possibly at the cost of lowering their status among members of the out-group. But grandstanding is sometimes broader in its aims, as when grandstanders try to impress people in general with their moral qualities. For example, in an effort to appear especially morally sensitive someone might say, "I had to pull over on the way to work this morning because I saw a homeless person and I just got so upset that some people have to live that way. This happens to me several times a month." Grandstanding for a general audience might not have its intended effect on everyone, of course, but its aim is broad, and not limited to any particular group.

Grandstanding can also come in more or less ambitious forms. Some grandstanders have modest goals, and try to show merely that they are decent people, or that they are members in good standing of their in-group. Others grandstand to gain prominence, or deference from others within their in-group, or a more general reputation as a moral sage. These grandstanders try to show others that they are not merely decent or average, but

\footnotetext{
${ }^{1}$ We discuss this account at greater length in Justin Tosi and Brandon Warmke, "Moral Grandstanding," Philosophy and Public Affairs 44, no. 3 (2016): 197-217; Justin Tosi and Brandon Warmke, Grandstanding: The Use and Abuse of Moral Talk (New York: Oxford University Press, 2020).
} 
morally exceptional. A related way of distinguishing types of grandstanding concerns different forms of status. Social psychologists have found that people pursue status through two broad strategies: gaining prestige and gaining dominance. ${ }^{2}$ Prestige status comes from people having a positive evaluation of you. For instance, people might recognize that you are smart, funny, or successful, and hold you in higher regard accordingly. Dominance status, on the other hand, comes from people being afraid that you might intimidate or coerce them. If others think that you pose a threat of this kind, they might be more likely to defer to you to avoid being targeted. Grandstanding can be used for both of these purposes. Grandstanders seek prestige status by trying to show others that they care deeply about morality, or have a keen moral sense, for example. They seek dominance status, on the other hand, by making people afraid that they might turn their moral talents against them. By threatening others with blame, shame, and social excommunication, you can gain dominance status. Building a reputation for actually doing these things can make you a high-status moral vanguard. ${ }^{3}$

As our account makes clear, grandstanding has a motivational component. Grandstanders are motivated to satisfy the Recognition Desire. Sometimes grandstanders are aware that they are contributing to public discourse to make themselves look good. They might even think to themselves something like, "If I say this, it will really impress my friends, and they'll see that I care deeply about justice." When we knowingly act on our

\footnotetext{
${ }^{2}$ Joey T. Cheng, Jessica L. Tracy, and Joseph Henrich, "Pride, Personality, and the Evolutionary Foundations of Human Social Status," Evolution and Human Behavior 31, no. 5 (2010): 334-47, https:/ / doi.org/10.1016/j.evolhumbehav.2010.02.004; Joseph Henrich, The Secret of Our Success (Princeton, NJ: Princeton University Press, 2015).

${ }^{3}$ It might be objected that there are really two phenomena here, and that only one qualifies as grandstanding. Whereas in some cases people use moral talk to look like moral exemplars (and these are the grandstanders), in other cases, people merely try to escape scrutiny by reassuring their audience that they are decent people. Perhaps such people are trying to protect themselves (maybe from other grandstanders), but not grandstanding themselves. In response, let's make two distinctions. The first concerns what one wants others to believe about oneself: one might want those in a certain reference network to think of one as especially morally enlightened, or instead as only morally decent (though even here, this decency will be typically framed in contrast to some other individual or group that fails to meet even this minimal standard). The second distinction concerns one's motivations for contributing to discourse: one kind of motivation concerns wanting to impress others by using moral talk to gain social status. Another motivation is defensive, whereby one uses moral talk to avoid scrutiny. The thing to notice here is that these distinctions are orthogonal. In our view, acting on a strong Recognition Desire aimed at either of the above target beliefs will generally count as grandstanding. Whether acting on the defensive motivation counts as grandstanding is a tricky question, but we can say two things. First, since motivations are often complex, if in such cases, one also acts on a strong enough Recognition Desire, this will likely count as grandstanding. Compare lying. People lie out of a motivation to deceive others. But they may also want to protect themselves, or spare others' feelings. Even so, these are still cases of lying. Second, even absent the Recognition Desire, one's behavior will still share many of the features of central cases of grandstanding and could then be thought of as either (1) a non-paradigmatic case of grandstanding; or (2) a distinct phenomenon altogether (call it "posturing") that is nonetheless closely related to grandstanding. For discussion of grandstanding as a prototype concept, see Tosi and Warmke, "Moral Grandstanding."
} 
Recognition Desire, this is called "witting grandstanding." But our motivations are not always so transparent to us. Much of our behavior is motivated by desires that are below the level of conscious awareness when we act on them. ${ }^{4}$ The explanations we give for our behavior, especially after the fact, are often self-serving. This suggests we often seek status for our alleged moral qualities even if we're unaware we're doing so. This is unwitting grandstanding.

It is also important to note that the set of motivations we act on is often complicated. Our motives are typically mixed and not singular. It might be tempting to think, then, that because most people want others to think well of them, morally speaking, they must always be motivated by that desire at least a little bit, and so everything they say must be moral grandstanding. But that would be a mistake. In our view, a person grandstands only if the Recognition Desire is a significant motivator for what she says. How significant? Here's a test: if someone would be disappointed to find out that no one in her audience came to think of her in the way she wants, then the desire is strong enough for her behavior to count as grandstanding. Of course, it's tricky to determine exactly how strong such a desire must be to trigger disappointment. But this is not unique to grandstanding. How much must you want to impress others in order for your speech to count as bragging? How much must you want to deceive others in order for your speech to count as lying? Our view, then, is that while the Recognition Desire needn't be the only motivation for the Grandstanding Expression, it must be a significant one.

Grandstanding is often paired with other phenomena in public discourse, but it is important to distinguish it from its frequent companions. Insincere cheap talk, for example, is commonly associated with grandstanding. Many people are apparently under the impression that accusations of grandstanding are necessarily charges of insincerity, and there is no doubt that many who issue such accusations mean them that way. But this is a mistake. Some grandstanding is undoubtedly insincere, with a speaker expressing a stance simply to pander to some audience in the moment. But grandstanding need not be insincere, and we suspect that it usually isn't. Many grandstanders probably really do believe the things they say, but that does not mean they aren't saying them with the aim of impressing others. And as we will see shortly, some of the most dangerous consequences of grandstanding arise because grandstanders sincerely believe the things they say.

If you learned about grandstanding simply from watching people accuse one another of it, you might get the idea that a Grandstanding Expression must be false. But this, too, is a mistake. To be sure, those accusing others of grandstanding usually disagree with the substantive content of the putative

\footnotetext{
${ }^{4}$ See Kevin Simler and Robin Hanson, The Elephant in the Brain: Hidden Motives in Everyday Life (New York: Oxford University Press, 2018). For fuller discussion, see William von Hippel and Robert Trivers, "The Evolution and Psychology of Self-Deception," Behavioral and Brain Sciences 34, no. 1 (2011): 1-16, https:/ / doi.org/10.1017/S0140525X10001354.
} 
grandstanding expressions they call out. This is probably because we are all more likely to make negative assessments of others' speech when we disagree with them, or when they are members of a competing tribe. But most of us can also, upon reflection, probably think of some people we agree with on substantive issues whom we also suspect of grandstanding, perhaps even while saying things we think are true. We will argue later that grandstanding can interfere with the search for truth in public discourse, but it is important to see that grandstanding may involve making true claims. By extension, it should be obvious that judging that someone is grandstanding does not license you to dismiss the substance of what she said. If a grandstanding expression can be true, then the fact that someone is grandstanding is not sufficient justification for concluding she is wrong.

It is no surprise that people grandstand. Large bodies of evidence in psychology show that most of us think we are morally better than the average person. ${ }^{5}$ Furthermore, our self-impressions as morally impressive people are important to us, and are largely influenced by how we see

\footnotetext{
${ }^{5}$ Mark D. Alicke et al., "The 'Better than Myself Effect'," Motivation and Emotion 25, no. 1 (2001): 7-22, https://doi.org/10.1023/A:1010655705069; David Dunning, "False Moral Superiority," in The Social Psychology of Good and Evil, ed. Arthur G. Miller, 2nd ed. (New York: The Guilford Press, 2016), 171-84; Nicholas Epley and David Dunning, "Feeling 'Holier Than Thou': Are Self-Serving Assessments Produced by Errors in Self- or Social Prediction?" Journal of Personality and Social Psychology 79, no. 6 (2000): 861-75; Detlev Fetchenhauer and David Dunning, "Perception of Prosociality in Self and Others," in Solidarity and Prosocial Behavior: An Integration of Psychological and Sociological Perspectives, ed. Detlev Fetchenhauer et al. (New York: Kluwer Academic/Plenum Publishers, 2006), 61-76, https://www.rug.nl/ research/portal/en/publications/perception-of-prosociality-in-self-and-others(5e1deb73d787-41b7-8b61-65472d68a940).html; George R. Goethals, "Social Comparison Theory: Psychology from the Lost and Found," Personality and Social Psychology Bulletin 12, no. 3 (1986): 261-78, https: / / doi.org/10.1177/0146167286123001; Nadav Klein and Nicholas Epley, "Maybe Holier, but Definitely Less Evil, than You: Bounded Self-Righteousness in Social Judgment," Journal of Personality and Social Psychology 110, no. 5 (2016): 660; Nadav Klein and Nicholas Epley, "Less Evil Than You: Bounded Self-Righteousness in Character Inferences, Emotional Reactions, and Behavioral Extremes," Personality and Social Psychology Bulletin 43, no. 8 (2017): 1202-12, https://doi.org/10.1177/0146167217711918; Ying Liu, "Investigating the Relation between Moral Self-Enhancement and Self-Deception: A Cross-Cultural Study of U.S. and Chinese College Students," Dissertations 279 (December 6, 2013), https: / /irl.umsl.edu/disser tation/279; Robert McGrath, "Character Strengths in 75 Nations: An Update," The Journal of Positive Psychology 10 (2015): 41-52, https: / / doi.org/10.1080/17439760.2014.888580; Constantine Sedikides, Lowell Gaertner, and Yoshiyasu Toguchi, "Pancultural Self-Enhancement," Journal of Personality and Social Psychology 84, no. 1 (2003): 60-70; Constantine Sedikides, Lowell Gaertner, and Jack L. Vevea, "Pancultural Self-Enhancement Reloaded: A Meta-Analytic Reply to Heine (2005)," Journal of Personality and Social Psychology 89, no. 4 (2005): 539-51; Constantine Sedikides and Mark D. Alicke, "Self-Enhancement and Self-Protection Motives," in The Oxford Handbook of Human Motivation, ed. Richard M. Ryan (New York: Oxford University Press, 2012), 303-22; Constantine Sedikides et al., "Behind Bars but above the Bar: Prisoners Consider Themselves More Prosocial Than Non-Prisoners," British Journal of Social Psychology 53, no. 2 (2014): 396-403, https://doi.org/10.1111/bjso.12060; Ben M. Tappin and Ryan T. McKay, "The Illusion of Moral Superiority," Social Psychological and Personality Science 8, no. 6 (2017): 623-31, https: / / doi.org/10.1177/1948550616673878; Paul A. M. van Lange and Constantine Sedikides, "Being More Honest but Not Necessarily More Intelligent than Others: Generality and Explanations for the Muhammad Ali Effect," European Journal of Social Psychology 28, no. 4 (1998): 675-80, https://doi.org/10.1002/(SICI)1099-0992(199807/08)28:4<675:AIDEJSP883>3.0.CO;2-5.
} 
ourselves in comparison to others. ${ }^{6}$ Given how much discussion there is about morality and politics, not just by politicians and political activists, but by billions of people on social media platforms, it would be surprising if people weren't using public discourse as a vanity project. In fact, our own empirical investigations of moral grandstanding suggest that it is relatively common in public discourse, and is equally distributed across the partisan divide. $^{7}$

\section{What Does Grandstanding Look Like?}

So far, we have given an account of what grandstanding is (and isn't). Perhaps that account has already called to mind some instances of the phenomenon. To see why grandstanding is a threat to free expression, it will be helpful to anticipate the kinds of discursive moves we can reasonably expect people to make when they grandstand, given basic facts about human psychology. Accordingly, we'll now offer a brief field guide to the forms grandstanding frequently takes. In other words, we'll explain how people grandstand.

But first, a word of caution is in order. In this section, we will explain why grandstanding often takes the form of, for example, excessive emotional displays. However, we are not claiming that every time someone shows excessive emotion in public moral discourse, she is grandstanding. In fact, our view is that grandstanding must be motivated to a significant degree by the Recognition Desire. Behavior that conforms to the surface characteristics laid out in this field guide is not grandstanding unless it also includes that motivational component. Sometimes excessive emotional displays are grandstanding; sometimes those displays have a different motivational basis. The point is that when people grandstand, the behaviors in this field guide are the things they are likely to do.

When groups discuss morality or politics, people sometimes chime in to contribute nothing more than a repetition or affirmation of what has already been said-perhaps many times. We call this phenomenon piling on. When people grandstand by piling on, they speak up simply to register their inclusion on the right side, or to pass themselves off as being involved in the action. Sometimes piling on is relatively costless, as when it simply clogs

\footnotetext{
${ }^{6}$ Leon Festinger, "A Theory of Social Comparison Processes," Human Relations 7, no. 2 (1954): 117-40; Mark R. Leary and Robin M. Kowalski, “Impression Management: A Literature Review and Two-Component Model," Psychological Bulletin 107, no. 1 (1990): 34-47, https: / / doi.org/10.1037/0033-2909.107.1.34; Sarah C. Rom and Paul Conway, "The Strategic Moral Self: Self-Presentation Shapes Moral Dilemma Judgments," Journal of Experimental Social Psychology 74 (2018): 24-37, https:/ /doi.org/10.1016/j.jesp.2017.08.003; Tappin and McKay, "The Illusion of Moral Superiority"; Andrew J. Vonasch et al., "Death Before Dishonor: Incurring Costs to Protect Moral Reputation," Social Psychological and Personality Science 9, no. 5 (2018): 604-613, https: / / doi.org/10.1177/1948550617720271.

${ }^{7}$ Joshua B. Grubbs et al., "Moral Grandstanding in Public Discourse: Status-Seeking Motives as a Potential Explanatory Mechanism in Predicting Conflict," PLOS ONE 14, no. 10 (2019): e0223749, https://doi.org/10.1371/journal.pone.0223749.
} 
up an unimportant discussion, or draws things out longer than necessary. Other times it is more damaging, as when people pile on blame or other hostile speech in cases of online shaming.

It's easy to see why grandstanding might take the form of piling on. If you want people to recognize that you hold the values of your in-group, an obvious way of achieving that aim is to register your views publicly, even if doing so just repeats what others have already said. The rationale is all the stronger in cases of online shaming, as your fellow in-group members might see you as contributing to the shared aim of taking down an enemy. ${ }^{8}$ On this point, it should be noted that there is sometimes substantial pressure to participate in pile-ons. If many of those from an in-group are piling on, silence can appear to be a sign of dissent, uncertainty, or impure beliefs. In such cases, even those who are unsure about whether they should join in may feel pressure to conform. ${ }^{9}$ People might also pile on to maintain their self-conceptions as dedicated members of an in-group. We think of ourselves partly in terms of how we compare to others. Psychologists call this "social comparison." 10 For instance, you might think of yourself as an unusually courageous and outspoken advocate for immigration reform. If others are piling on about the need for state action on that issue, you might understandably feel the need to insert yourself in the discussion, even if you have little to add. After all, since you think of yourself as courageous and outspoken on this issue, it would be strange if people were discussing it and you didn't make an appearance.

Much grandstanding takes the form of ramping up. This happens when contributors to a public discussion make increasingly strong claims about the matter under discussion. Grandstanding-driven ramping up makes public discourse look like a moral arms race. You have probably seen conversations, online or in other media, that have this sort of dynamic:

Person 1 "I was so disappointed to see those protestors burning the American flag. I know it's legal, but the media should at least refrain from showing it on television."

\footnotetext{
${ }^{8}$ M. J. Crockett, “Moral Outrage in the Digital Age," Nature Human Behaviour 1, no. 11 (2017): 769, https://doi.org/10.1038/s41562-017-0213-3; Kathryn J. Norlock, "Online Shaming," Social Philosophy Today 33 (2017): 187-97, https: / / doi.org/10.5840/ socphiltoday201762343.

${ }_{9}^{9}$ On conformity, see Solomon E. Asch, "Studies of Independence and Conformity: A Minority of One against a Unanimous Majority," Psychological Monographs: General and Applied 70, no. 9 (1956): 1-70; Rod Bond and Peter B. Smith, "Culture and Conformity: A Meta-Analysis of Studies Using Asch's Line Judgment Task," Psychological Bulletin 119, no. 1 (1996): 111-37, https: / / doi.org/10.1037/0033-2909.119.1.111; Rom and Conway, "The Strategic Moral Self"; Carey S. Ryan and Laura M. Bogart, "Development of New Group Members' In-Group and Out-Group Stereotypes: Changes in Perceived Group Variability and Ethnocentrism," Journal of Personality and Social Psychology 73, no. 4 (1997): 719-32; Cass R. Sunstein, Conformity: The Power of Social Influences (New York: New York University Press, 2019); Robb Willer, Ko Kuwabara, and MichaelW. Macy, "The False Enforcement of Unpopular Norms," American Journal of Sociology 115, no. 2 (2009): 451-90, https:/ / doi.org/10.1086/599250.

${ }^{10}$ Festinger, "A Theory of Social Comparison Processes."
} 
Person 2 "'Disappointed' doesn't even begin to describe how I feel about this. I think it's time to reopen the question of whether this is protected speech in the courts, because it is absolutely despicable to disrespect what our troops have fought for like that."

Person 3 "I'm so sick of hearing all these namby-pamby ideas about what to do with flag-burners. Every true American knows exactly what must be done. Any traitor who so much as looks funny at the flag should be sent straight to Guantanamo with the other terrorists!"

Grandstanding manifests itself in ramping up due to well-understood features of our psychologies. For most of us, our self-conceptions partly depend on how we think we measure up against others. ${ }^{11}$ Other peoples' behavior affects both how we think of ourselves and how we appear to others, since those judgments are so often based on comparisons. Suppose you thought of yourself as caring deeply about the poor, or about the troops. It can be difficult to maintain this self-assessment once others reveal their own moral views about some matter under discussion. They might look like the ones who care most. Therefore, to maintain both your self-assessment and reputation as being the person who cares the most about the poor, you must outdo others, to show that you care more about the poor than they do. Of course, once your "position" is revealed, others gain an incentive to ramp up with an even stronger claim, by saying something they believe others will see as revealing an even deeper, more serious concern for the poor. And off we go. ${ }^{12}$ Of course, not all "ramping up" is driven by grandstanding-sometimes people simply disagree about some issue, and instead think some stronger claim is warranted purely on the merits. But people also try to outdo others to stand out, gain attention, and look like moral paragons either to an in-group or an out-group. This competitive attention seeking leads people to adopt (or at least express) radical views. These views are unlikely to be true, given that they are adopted as part of an attention-seeking process. Grandstanding-driven ramping up also contributes to a polarized political environment. Where there is pressure to ramp up, the positions of the opposing sides of an issue will tend to move away from each other, and the middle ground will be seen by each side as requiring unacceptable moral compromise.

Grandstanders are likely to be moralizers, always searching for new features of the world to occasion a demonstration of their moral qualities. ${ }^{13}$

\footnotetext{
${ }^{11}$ Festinger, "A Theory of Social Comparison Processes"; Goethals, "Social Comparison Theory."

${ }^{12}$ Cass R. Sunstein, "The Law of Group Polarization," Journal of Political Philosophy 10, no. 2 (2002): 175-95, https:/ / doi.org/10.1111/1467-9760.00148.

${ }^{13}$ On moralism see Julia Driver, "Moralism," Journal of Applied Philosophy 22, no. 2 (July 25, 2005): 137-51, https:/ / doi.org/10.1111/j.1468-5930.2005.00298.x; Robert K. Fullinwider,
} 
This results in what we call trumping up-insisting that there is a moral problem where in fact there is none. ${ }^{14}$ It's difficult to give an example that would be universally accepted, but we are reminded of a minor dust-up in American politics that occurred in 2014. In a technical violation of saluting protocol, President Barack Obama saluted two U.S. Marines while holding a coffee cup. Republican strategist Karl Rove criticized the President, saying "the idea that I'm going to just jaunt out there with my chai tea, and give them the old ... I mean please, how disrespectful was that?"15 We can't say for certain whether Rove was grandstanding, but we do think this is a pretty good example of trumping up. It takes an extraordinarily sensitive "moral compass" to object so strongly to such a trivial matter. Not surprisingly, trumping up often involves conjuring up things to blame others for. At some level, grandstanders must know that criticizing others is a way to manage others' impressions of you, as being a reliable judge of morality, for example. ${ }^{16}$

Of course, sometimes an insightful and well-intentioned person alerts us to a real moral problem that has escaped the attention of most observers. So not every claim of a new moral problem is a mark of grandstanding, or of trumping up. But there is also a considerable amount of moral entrepreneurship in making moral claims. After all, what better way to show that you are more attuned to moral matters than by finding novel ways to criticize others for their moral failures? What passes as morally decent among the benighted masses does not escape the ever-critical eye of the grandstander. Ramping up and trumping up account for much of the exaggeration and hyperbole you see in public discourse.

We can manage others' impressions of us not only through the substance of what we say, but also through the emotions we express. ${ }^{17}$ This fact is not

“On Moralism," Journal of Applied Philosophy 22, no. 2 (2005): 105-120; Craig Taylor, Moralism: A Study of a Vice (Montreal: McGill-Queen's University Press, 2012).

${ }^{14}$ Trumping up requires getting something wrong. Typically, this will involve saying something false. It might seem like we are reneging on our claim that a grandstander need not say anything false. However, even though grandstanding expressions as such need not be false, some forms of grandstanding involve making a mistake. Trumping up is one such form. So while not all Grandstanding Expressions are false, some are.

15 https: / /insider.foxnews.com/2014/09/23/\%E2\%80\%98how-disrespectful-was-that $\%$ E2\%80\%99-karl-rove-blasts-obama\%E2\%80\%99s-\%E2\%80\%98latte-salute\%E2\%80\%99 [last accessed $10 / 2 / 19]$

${ }^{16}$ Jillian Jordan et al., "Why Do We Hate Hypocrites? Evidence for a Theory of False Signaling," SSRN Scholarly Paper (Rochester, NY: Social Science Research Network, January 11, 2017), https://papers.ssrn.com/abstract=2897313; Jessica Kennedy and Maurice E. Schweitzer, "Holding People Responsible for Ethical Violations: The Surprising Benefits of Accusing Others," Academy of Management Proceedings 2015, no. 1 (2015): 112-58, https: / / doi. org/10.5465/ambpp.2015.11258abstract; Philip E. Tetlock, "Social Functionalist Frameworks for Judgment and Choice: Intuitive Politicians, Theologians, and Prosecutors," Psychological Review 109, no. 3 (2002): 451-71.

${ }^{17}$ Jeffrey D. Green et al., "Self-Enhancement, Righteous Anger, and Moral Grandiosity," Self and Identity 18, no. 2 (2019): 201-16, https:/ / doi.org/10.1080/15298868.2017.1419504; Linda J. Skitka and Daniel C. Wisneski, "Moral Conviction and Emotion," Emotion Review 3, no. 3 (2011): 328-30, https:/ / doi.org/10.1177/1754073911402374. 
overlooked by grandstanders, who frequently seize opportunities to impress others with excessive emotional displays. Grandstanders might aim to show others just how much they care about moral matters by, for example, expressing over-the-top outrage about a case of injustice, sadness about the plight of the poor, or vengeful anger at the polluters who are destroying the environment.

Notice we are not claiming that it is inappropriate to feel or express moral emotions - even very strongly—about these cases or similar ones. ${ }^{18}$ But it is naïve to think that emotions like moral outrage are always expressed for noble reasons. Sometimes people express outrage to alleviate their own guilt. ${ }^{19}$ Some express outrage just because it feels good, indulging in so-called moral outrage porn. ${ }^{20}$ Grandstanders have an incentive to use such emotions demonstratively, and for their own ends, rather than to advance the causes that might appropriately evoke those emotions. Worse yet, because grandstanders often try to stand out, they will sometimes overdo it with expressions of emotion, so that their reactions are excessive. Think for instance of the public mourners in North Korea after the death of Kim Jong Il, who made international news for their theatrical wailing during their dear leader's funeral procession. Not all grandstanding through displays of strong emotions is so artless, of course, but it can still be excessive.

Grandstanders often treat anyone who disagrees with them as beneath contempt, unworthy of even having a conversation with. If you want people to think you are morally impressive, acting like virtually everyone else's moral and political views are contemptuous is an obvious tactic. Grandstanders often come off as dogmatic know-it-alls. ${ }^{21}$ Naturally, then, one tool of the grandstander's trade is dismissiveness, the last common form of grandstanding we discuss here. We all know that there are some views that can be rightly dismissed or ignored, at least in many contexts. Were someone to chime in with a defense of slavery during an online discussion of minimum wage laws, that view need not be treated with serious attention-it can be denounced and dismissed. Grandstanders, like the rest of us, know and accept this norm. However, grandstanders also know that dismissiveness can be used to set oneself up as the authority concerning what views may be discussed in the company of morally decent people. You have perhaps seen people say things like, "I can't believe you're actually suggesting there's

\footnotetext{
${ }^{18}$ Although we do find dispassion attractive as an ethical ideal. See Jeremiah Carey, "Dispassion as an Ethical Ideal," Ergo, an Open Access Journal of Philosophy 5 (2018), http:/ / dx.doi. org/10.3998/ergo.12405314.0005.024.

${ }^{19}$ Zachary K. Rothschild and Lucas A. Keefer, "A Cleansing Fire: Moral Outrage Alleviates Guilt and Buffers Threats to One's Moral Identity," Motivation and Emotion 41, no. 2 (2017): 20929, https: / / doi.org/10.1007/s11031-017-9601-2.

${ }^{20}$ Green et al., "Self-Enhancement, Righteous Anger, and Moral Grandiosity"; C. Thi Nguyen and Bekka Williams, "Moral Outrage Porn," Journal of Ethics and Social Philosophy 18, no. 2 (2020), PhilArchive copy v2: https: / / philarchive.org/archive/NGUMOPv2.

${ }^{21}$ For insight into "know-it-all society," see Michael P. Lynch, Know-It-All Society: Truth and Arrogance in Political Culture (New York: Liveright, 2019).
} 
even a question about whether abortion is permissible. We can't normalize these retrograde views by giving them the time of day." Speech like this conveys moral certainty, which many associate with moral purity.

\section{Grandstanding And Ideals of Free Expression}

Defenders of free expression have offered no shortage of reasons to think it is important or valuable, and we will not attempt to survey those considerations in this essay. In specifying some ideals of free expression that moral grandstanding threatens, however, it will be useful to appeal to a couple of popular reasons to value free expression. For one thing, many moral and political philosophers have argued that freedom of expression is an especially important component of individual autonomy. Most famously, John Stuart Mill argued that free expression falls under the principle of freedom of conscience, since it is "almost of as much importance as the liberty of thought itself," and "is practically inseparable from it." 22 The general idea is that if people are not free to express themselves as they wish, they are thereby stunted in the development of their individuality, and so not autonomous. A second and related reason that some, including Mill, have cited as a reason to value free expression is that it is an important condition for promoting the pursuit of truth. The relationship between free expression and the truth is complicated, but in a nutshell, when people are free to express themselves, they are generally better able to consider the evidence and arguments that might lead them and others to discover the truth.

While we might care about freedom of expression for many other reasons, these two are good starting points for making sense of some ideals of free expression that we hope public discourse might realize. We'll discuss three such ideals, and argue that grandstanding interferes with the realization of each of them. We will not argue in any great detail for these ideals of free expression. But many readers will find them, or something close, to be desirable ideals of public discourse. If you agree that these ideals of free expression are desirable, then you should also be concerned if grandstanding interferes with them.

In other work, we have argued at length that grandstanding is generally morally bad and should be avoided.$^{23}$ We provided three different families of arguments, showing that the use of moral talk for self-promotion and status seeking has significant social costs, that it disrespects others, and that a virtuous person would not do it. We won't rehash those arguments here, but we will introduce a new consideration for assessing the value of grandstanding. Where grandstanding is common and rewarded, it interferes with the pursuit of the ideals of free expression.

\footnotetext{
${ }^{22}$ John Stuart Mill, On Liberty and Other Essays, ed. John Gray (Oxford: Oxford Paperbacks, 2008), 17.

${ }^{23}$ Tosi and Warmke, "Moral Grandstanding"; Tosi and Warmke, Grandstanding.
} 


\section{A. Popular views should be challenged regularly}

First, it is an important feature of a healthy public discourse for popular views to be regularly subjected to criticism. There is nothing inherently wrong with a group having a popularly held view about some issue in morality or politics. A community might converge on a shared belief for any number of perfectly innocent or even laudable reasons. But if people are able to think and speak freely about their beliefs, even true believers will discover nagging doubts, and they should be allowed to voice those doubts. By the same token, critics of popular views should be free to present their objections to those views.

It is worth noting that when we say expressions of opinion should be "free," we do not mean merely free from legal intervention, though that's part of the idea of free expression. Free expression also means being generally free from social sanctioning. A society can hardly claim to allow for free expression when challenging popular views incurs a significant risk of losing friends, family, and employment opportunities, even if the expression is legally permissible. "Freedom" as we use it means freedom from unreasonable costs, broadly speaking.

This ideal is attractive because when a community realizes it, it promotes both individual autonomy and truth-seeking. To see why, consider John Stuart Mill's famous argument about what happens when certain beliefs are held sacred and thus not subjected to critical examination. Rather than being maintained as "living truths," well-understood and endorsed in all their complexity, such doctrines instead become "dead dogmas." ${ }^{24}$ People forget why they hold such beliefs, and why they reject alternative views. As Mill puts it, "[h]e who knows only his own side of the case ... knows little of that." ${ }^{25}$ Good reasons to endorse a view on some matter are not so easily separated from reasons to reject what is false, and some of these considerations are best brought to light by considering arguments against what is true. Mill's own approach to this issue is still apt. We need to hear the best available arguments against what we believe from people who actually hold contrary views. Our epistemic bubbles and echo chambers prohibit us from hearing opposing views and taking them seriously. ${ }^{26}$ We get to hear and seriously consider those arguments by actively encouraging dissenters to challenge popular and even sacred beliefs.

Now let us imagine a public discourse where many people grandstand and it's rewarding for them to do so. The rewards are various: the pleasure from thinking and acting like one is morally superior to others, the social prestige that can come with being seen as morally superior, and the social dominance that can be effective for silencing critics and getting one's way, to

\footnotetext{
${ }^{24}$ Mill, On Liberty and Other Essays, 40.

${ }^{25}$ Mill, On Liberty and Other Essays, 42.

${ }^{26}$ C. Thi Nguyen, "Echo Chambers and Epistemic Bubbles," Episteme 17, no. 2 (2020): 141-61, https://doi.org/10.1017/epi.2018.32.
} 
name a few. The more this behavior is rewarded, the less likely it is that popular views about morality and politics will be challenged.

To see why, suppose that within some group, a certain policy proposal is popular. As we have said, it is ideal that members of the group hear and discuss challenges to their views. To appreciate how grandstanding might interfere with that ideal, we can consider the possible sources of challenges to the group's favored view, and the incentives and disincentives for issuing those challenges.

One possibility is that someone within the group itself could challenge the dominant view. If the group is seriously committed to finding the truth, or the optimal solution to a problem, then group members will be incentivized to voice their doubts, or at least to play devil's advocate by imagining reasonable cases for dissent. The same might be true if group members think it is important to try living according to different values, for the sake of exploring their individuality.

When status can be gained within a group through grandstanding, however, there are contrary incentives. The easiest and surest way to impress your fellow group members in that case is simply to tell people what they want to hear. Repeat what has already been said, or add your own personal twist to a slogan that has already been approved and which others have used to enhance their status. Mock and dismiss weak or idiotic versions of objections that might be raised by opponents. Show how angry you are that anyone could be so foolish as to disagree with what everyone in the groupor everyone who deserves to be there, at any rate- -knows to be true. If this is what people are doing in a discussion with apparently like-minded peers who you want to impress, and it is all going over well, then introducing dissenting ideas and taking them seriously could really stink up the room.

In such conditions there are strong pressures to conform to the group's popularly held views. ${ }^{27}$ If you have a good objection to the group's dominant view, but grandstanding is prevalent in the discussion, the prudent move might be to keep your thoughts to yourself. If you decide to be adventurous, then you will be making yourself a vulnerable target for grandstanders. Worse yet, sometimes people are incentivized not only to keep heterodox thoughts to themselves, but to engage in grandstanding of their own. That is, not only is grandstanding rewarded, but refraining from grandstanding is evidence of a moral defect. Thus, if some brave soul makes a comment critical of group orthodoxy, the rest of the group has an incentive to chime in with a stern correction. If they don't, then they risk accusations of cowardice or apostasy.

But what about groups that incentivize playing devil's advocate? In at least some groups, you can earn status and be thought of as morally impressive for challenging your group's beliefs. In groups like that, even if a discussion were overrun by grandstanders, this ideal of free expression

${ }^{27}$ Sunstein, Conformity. 
could still be attained. This is, of course, a possibility. But this scenario requires that the social incentives are such that the devil's advocate can reasonably think her dissent within her group will impress others. In our estimation, this is both uncommon and, given the psychology of group dynamics, unlikely. What binds real-life coalitions is a high level of conformity around moral and political convictions. There is powerful social pressure not to rock the boat and be seen as the "black sheep" of your in-group. This does not mean that group members never rock the boat. Rather, the point is just that if your goal is to impress your in-group, dissenting from what binds them will probably not only fail to impress many, but also backfire. If your strategy for ensuring that popular views are regularly challenged is to rely on status-seeking individuals to make waves in their group, you probably won't see many challenges.

Another possibility is that members of an out-group might issue worthwhile challenges to the in-group's views. Such challenges might spark fruitful intergroup dialogue, or at least discussion of the objection among in-group members. On the face of it, there is some reason to expect this to happen even when grandstanding is common in public discourse. Members of the out-group might impress their likeminded friends by coming up with compelling objections to the views of some opposing group. But if these outgroup opponents are out for recognition from their friends, there is reason to think they won't give the best arguments available. It is easier to attack a caricature of a view, and since out-group members can score points by affirming their own competing values, the primary goal among grandstanders will be to show that they think the other group's views are ridiculous. In fact, if someone takes pains to reconstruct the most charitable rationale for believing as opponents do, she risks being accused of harboring too much sympathy for vicious ideas by opportunistic grandstanders among her tribe. It will typically be safer, then, to reassure the people you want to impress both that they are obviously right and that even a cursory inspection of opposing views reveals devastating flaws. In short, when grandstanding is common, out-group members will be of little help to the in-group, because they will mainly be interested in caricaturing and then dismissing the in-group's views as embarrassing. And even when outgroup members buck the incentives and offer good objections, in-group members might be wise to ignore them, lest they be accused of taking the corrupt "talking points" of the other side too seriously.

\section{B. Freedom to entertain new and heterodox ideas}

In a society where free expression is respected, people should be able not only to challenge popular ideas, but also to entertain alternatives in open discussion. This is the positive version of the first ideal. The freedom to criticize is important, but so is the freedom to advocate for alternatives, whether they are just new and unfamiliar or also turn out to be heterodox. 
Even if dissenters raise doubts about a popular position, unless a potentially better alternative can be forwarded, the criticism may be fruitless. People should be free to discuss the merits of new ideas and to revisit old ideas that are socially unpopular. People should be able to introduce propositions in public without a general presumption of the truth or falsehood of those propositions. Moreover, discussion of any proposition should be free in the sense that there is generally no pressure to come to any particular conclusion outside of the strength of the considerations raised through arguments and evidence.

This ideal too is worthy on both autonomy and truth-seeking grounds. An important part of working out your own individuality is trying out different ideas and seeing what makes the most sense to you. An environment in which people are limited to their own internal consideration of ideas, or discussion only among those with whom they agree, is stifling for personal development. It is unlikely that someone will be able to think of all the best considerations for and against any given idea without input from others. And if the people with whom you can safely discuss an idea are limited to those with whom you agree, it is also unlikely that the idea will be subjected to the worthiest challenges or given the strongest possible support. It will thus be difficult for a person to evaluate an idea without availing herself of open discussion about it. For the very same reasons, it is important to discuss ideas openly and broadly in order to discover whether they are true. Limiting the discussion of an idea is a good way to protect it from challenge, or alternatively to insulate yourself from hearing the best case for it. Ideas tend to stand or fall on their merits when they are discussed openly, and they survive or die out for reasons irrelevant to their truth-value when discussion of them is confined to the shadows.

An example from the college classroom illustrates the power of social sanctioning to limit free expression. We are both philosophers and often teach courses on controversial moral issues: abortion, immigration, pornography, reparations, and the like. In our experience, most students have a general sense of what the dominant positions are within their age group. They can also read a room. They know that what they say in a class of fifty or a hundred students can have profound effects on how they are viewed and treated by their peers. When uncomfortable issues come up in courses like ours, students are often initially reluctant to speak up. Even students who disagree with one another exchange looks that say "I'm not stepping in this." Students' questions in environments like this often come with long personal disclaimers about their personal backgrounds and beliefs (for example, "I go to church every week and I would never even think of having an abortion, and I know this is wrong, but what if someone said it's OK to have an abortion because X?"). One of the most important skills for teaching a class like this is the ability to create an environment where students move past their discomfort and feel safe to follow arguments where they lead. Our understanding of free expression implies that people in similar 
circumstances should be able to explore or defend the philosophical merits of even highly heterodox views. According to this ideal, they should be free from the threat of ostracism, ridicule, name-calling, or "othering" simply for expressing curiosity about heterodox ideas, doubts about popular ones, or even interest in the philosophical foundations of popular views of the other side that they do not fully understand.

But many college students don't feel free to express their opinions. According to a 2017 Gallup/Knight Foundation survey, 61 percent of U.S. college students say that campus climate prevents people from speaking freely (an increase from 54 percent the previous year). ${ }^{28}$ Students are increasingly afraid of being attacked (59 percent) or "blocked" (60 percent) by those who disagree with their views. In a rare case of ideological agreement, whereas roughly 90 percent of both liberals and conservatives say liberals are free to express their opinions, only about 60 percent of both liberals and conservatives say the same about conservatives.

We argued earlier that a grandstanding-rich environment is not conducive to the discussion of criticisms of popular views. But what about the consideration of alternative ideas? It is logically possible for the former to be frowned upon and the latter tolerated, and there are plausible reasons to be hopeful that grandstanding will not interfere with expressions of new or heterodox ideas. But here, too, a thorough examination of the incentives that speakers face in a public discourse dominated by grandstanding will reveal that such an environment is inhospitable to free expression.

Recall that grandstanding sometimes takes the form of ramping up-the phenomenon of speakers making increasingly stronger claims about the matter under discussion. Ramping up can gain a grandstander higher status within a group by establishing her as someone with purer beliefs than others, for instance. In some cases, ramping up could involve grandstanders advancing new ideas, as they take the values of the in-group so far that they end up expressing support for new ideas as a way of intensifying their position. So, for example, a series of ramped-up comments about how the government should raise the minimum wage and support unions could eventually lead to someone saying that these proposals are not radical enough, and the government should nationalize the means of production. Alternatively, in a discussion about how much income tax rates should be cut to promote growth, someone might offer that, actually, all taxation is theft, and the income tax must be abolished entirely. Different

\footnotetext{
${ }^{28}$ https: / / news.gallup.com/poll/229085/college-students-say-campus-climate-detersspeech.aspx [last accessed 10/2/19]. This survey of 3,104 randomly sampled college students is a follow-up to a nationally representative 2016 Knight Foundation/Newseum Institute/Gallup survey. See: https://www.knightfoundation.org/reports/free-speech-campus [last accessed 10/2/19]. https://news.gallup.com/poll/229085/college-students-say-campusclimate-deters-speech.aspx [last accessed 10/2/19]. This survey of 3,104 randomly sampled college students is a follow-up to a nationally representative 2016 Knight Foundation/Newseum Institute/Gallup survey. See: https:/ / www.knightfoundation.org/reports/free-speechcampus [last accessed 10/2/19].
} 
manifestations of grandstanding could lead to similar expressions of heterodox ideas. People could stumble upon ideas at odds with those favored by other in-group members when they trump up spurious moral claims, for example.

The point is that because grandstanders have some incentive to explore new moral terrain, they might sometimes gain status by endorsing alternative ideas - or at least reasonably hope to do so. Being a trendsetter in moral discourse involves taking risks and saying things that people aren't already saying. Unfortunately, however, grandstanders' incentives to advance alternative ideas are highly limited. Since the fundamental aim of grandstanding is to gain recognition from others for your moral credentials, grandstanders have less incentive to make any given moral claim as it becomes increasingly uncertain that they will actually gain that recognition. Those who think they see an opportunity to say something new must weigh the possible benefit of a positive response against the risk of a negative one. The safer play for grandstanders is to keep their claims within the comfort zone of their in-group, limiting the degree to which they push boundaries.

Even when new ideas are introduced in a grandstanding-rich environment, this will often make people uneasy about how to interact with them. Why? When a new idea is introduced to a group, there may be a great deal of uncertainty about how the audience will think about its contributor. Perhaps people will think this trendsetting idea is the mark of a truly keen moral insight and that this person is on the new frontier of morality, a trailblazing reformer. If that's how the idea is taken, then agreeing with it and amplifying it can impress onlookers. On the other hand, group members may instead use the opportunity to attack this poor benighted soul for uttering such morally backward drivel, and by doing so, raise their own status within the group. There can be genuine uncertainty about which way things will go, and for this reason, people may decide that interacting with the idea is just not worth the risk. It might just be ignored.

It isn't always clear how new ideas fit in with the old. Even if you've thought through an issue carefully, anticipated possible objections to your new idea, and adjusted accordingly, you can't be sure how people will react to an untested claim. Advancing heterodox ideas could pay off handsomely, but the risk is high. And the more grandstanding there is in public discourse, the riskier it is to stray from what is familiar. It is typically safer to stick to what people know and love, repeating tried and true slogans about justice or family values that are guaranteed crowd-pleasers. By eschewing the heterodox and instead saying all the right things, you can reassure people that you affirm your in-group's cherished values.

In short, when grandstanding is common and rewarded in a group's discussions, the expression of new and heterodox ideas is disincentivized. Instead, conformity is rewarded, and so conformity is what such groups' 
discussions yield. In terms of the first two ideals of free expression and their underlying moral basis, this is an important loss. Grandstanding crowds out both the pursuit of truth and curiosity for its own sake, and replaces it with status seeking using the familiar.

\section{Low cost of changing your mind}

When people engage in free and open discussion, they are likely at least sometimes to be moved by arguments and evidence into changing their minds, even when it comes to beliefs about which they were once confident. Whether they actually do change their minds, however, will depend not just on epistemic considerations, but on the social costs of doing so. Some examples of the costs we have in mind include things like being treated as a traitor to the cause, or as an embarrassing failure. Alternatively, others might assume that those who change their minds can only have done so in bad faith. Roughly speaking, we are thinking of any social result of changing your mind that you might dread. ${ }^{29}$

Ideally, the costs of changing one's mind should not be high. If they are high, then there is a disincentive to take opposing views seriously, or to listen to them at all. Why risk being moved to do something that will come with unpleasant consequences when you can easily avoid the sources of such trouble? Such costs also encourage motivated reasoning. If coming to a certain conclusion will make your life more difficult, you might understandably look harder for ways to avoid that conclusion. Perhaps you will even be seduced by a plausible-sounding but fallacious objection to the argument, and thus satisfy yourself that you can stop thinking about it and retain your comfortable belief. Of course, even if you avoid these intellectually lazy routes and change your mind when met with a cogent argument, social costs might discourage you from speaking up about your new beliefs. In other words, if the costs of changing your mind are high enough, we should expect discrepancies between what people profess to believe and what they actually believe.

On the other hand, if the costs of changing your mind are low, people are freer to consider the arguments on their merits, and enjoy more freedom to follow their conscience. This provides no guarantee that people will discover the truth. Removing one source of bias doesn't turn us into perfect reasoners. But it does at least mean we'll be less likely to make mistakes because of one form of epistemically irrelevant social pressure. We are also freer to explore ideas as part of the development of our individuality when social pressure is reduced.

\footnotetext{
${ }^{29}$ A related possibility is that there could be benefits to changing your mind very publicly that might also distort peoples' tendencies to respond appropriately to arguments and evidence. For instance, you might be celebrated by the other side, secure lucrative speaking engagements or book deals, and so on, as some will be interested to hear about the person who saw the light, what finally proved to be too vicious about the enemy to be tolerated, or whatever else.
} 
When people are free to express their opinions, the costs of publicly changing your mind about morality or politics will be low. However, grandstanding-saturated discourse increases these costs. And when the costs are high, fewer people will make known when they've changed their minds due to the incentives. In fact, of the three ideals of free expression we've discussed, this is where grandstanding likely has the greatest smothering effect. One can challenge popular views or entertain heterodox ones and still assert one's membership in the group that thinks it's on the right side of history. You might raise doubts about your moral credentials (and deal with the fallout we discussed above), but you can still assert your right-thinking convictions at the end of the day. Challenges to your in-group's popular views can be deployed strategically to preserve at least the veneer of true-believer status: "Look, like all of you I think the Second Amendment should never be repealed, but isn't our current situation a little different from the eighteenth century?" By expressing doubts, you will raise suspicion about your moral purity within your group. But publicly admitting that you were wrong and have now changed your mind will remove all doubt. It takes courage to abandon publicly the views of your in-group. Even more courage is required when public discourse is overrun by status-seeking grandstanders.

Status-seeking discourse inhibits the public changing of minds through many of the same mechanisms we have already discussed. Grandstanding transforms moral talk into a series of purity tests, where your moral qualifications are judged according to whether you affirm your group's dogmas. Few want to look like they possess an unreliable moral compass by challenging a popular view. But even fewer want to be seen as apostates to the cause. And sincerely defecting from your group's dogma, even if only on a single issue, can be a fast track to social excommunication.

In fact, being the black sheep in your group tends to lead them to judge you more unfavorably than they judge those in the out-group. This so-called "Black Sheep Effect" underscores just how important our tribal identities are to us, and the lengths to which many of us will go to defend them. ${ }^{30}$ Your principled opponents on the other side are at least to be praised for consistency, even if they are wrong. And those on the other side who are inconsistent can be useful, to serve as occasional allies. But to have those in your own group defect-that's betrayal. Unreliable in-group members are traitors. Few people want to be thought of and treated as the black sheep of their group. The more grandstanding there is, the less often people will change their minds, or at least admit having done so. The personal and social costs are too rich for most peoples' blood.

\footnotetext{
${ }^{30}$ José M. Marques, Vincent Y. Yzerbyt, and Jacques-Philippe Leyens, "The 'Black Sheep Effect': Extremity of Judgments towards Ingroup Members as a Function of Group Identification," European Journal of Social Psychology 18, no. 1 (1988): 1-16, https://doi. org /10.1002/ ejsp.2420180102; Isabel R. Pinto et al., "Membership Status and Subjective Group Dynamics: Who Triggers the Black Sheep Effect?" Journal of Personality and Social Psychology 99, no. 1 (2010): 107-19.
} 


\section{A Concluding Observation}

This essay is about a basic problem: status seeking in public discourse in the form of moral grandstanding. In our view, grandstanding increases the costs of expression that might not please crowds, and so makes it less free. We've approached this conclusion from three different angles, looking at the incentives involved in challenging popular ideas, proposing heterodox ones, and changing your mind. In our estimation, the more people engage in public discourse to gain status by seeking prestige and exerting dominance, the less free our discourse will be.

Suppose we are wrong about the effect of grandstanding on those elements of free expression. You should still be concerned with the effects of grandstanding on free expression, especially if you think that free expression is an important condition for promoting the pursuit of truth. Public discourse dominated by grandstanding is not a reliable method of arriving at the truth. Grandstanders are responding to the incentives to gain social status and impress their peers. But there is little reason to think that trying either to impress those in your peer group or dominate those in your outgroup is a reliable method of arriving at the truth. And even if you did arrive at the truth, this would be an accident. People would lack any kind of rational explanation or justification for arriving at the conclusions they do, though they might of course concoct such rationalizations after the fact. Grandstanding is therefore in conflict with truth-seeking. Whatever your assessments of our other arguments in this essay, this alone suggests that we need norms discouraging grandstanding and promoting behavior more conducive to truth-seeking.

Philosophy, Texas Tech University, USA

Philosophy, Bowling Green State University, USA 